\title{
Does a University's Enslavement History Play a Role in Black Student-White Faculty Interactions? A Structural Equation Model
}

\author{
Juan C. Garibay ${ }^{1, *}$ and Christopher Mathis ${ }^{2}$ \\ 1 Department of Education Leadership, Foundations and Policy, University of Virginia, \\ Charlottesville, VA 22904, USA \\ 2 College of Law, University of Iowa, Iowa City, IA 52242, USA; christopher-mathis@uiowa.edu \\ * Correspondence: jcg6m@virginia.edu
}

Citation: Garibay, J.C.; Mathis, C. Does a University's Enslavement History Play a Role in Black Student-White Faculty Interactions? A Structural Equation Model. Educ. Sci. 2021, 11, 809. https://doi.org/ 10.3390/educsci11120809

Academic Editors: Sylvia Hurtado and Krystle Palma Cobian

Received: 4 September 2021

Accepted: 10 December 2021

Published: 14 December 2021

Publisher's Note: MDPI stays neutral with regard to jurisdictional claims in published maps and institutional affiliations.

Copyright: (c) 2021 by the authors. Licensee MDPI, Basel, Switzerland. This article is an open access article distributed under the terms and conditions of the Creative Commons Attribution (CC BY) license (https:// creativecommons.org/licenses/by/ $4.0 /)$.

\begin{abstract}
Drawing upon Hartman's (1997) notion of the afterlife of slavery and Critical Race Quantitative Inquiry, this study examines whether Black college students' emotional responses to their institution's history of slavery plays a role in contemporary interactions with white faculty. Using structural equation modeling techniques on a sample of 92 Black students from a southern U.S. institution historically involved in slavery, findings highlight the significance of background characteristics, students' emotional responses to their institution's slavery history, and experiences with racial microaggressions during college in predicting negative interactions with white faculty. Implications for research, policy, and practice are discussed.
\end{abstract}

Keywords: black undergraduates; student-faculty interactions; cross-racial experiences; historical legacies of slavery in higher education; Critical Race Quantitative Inquiry; afterlife of slavery

\section{Introduction}

Numerous studies have shown that students have positive educational outcomes when they have quality interactions with faculty members [1-11]. Positive student-faculty interactions are positively associated with students' degree aspiration [1], perceptions of the campus environment [12], academic achievement, intellectual and personal development, and retention [7]. However, these early studies largely focused on experiences with faculty, generally, rather than developing more nuanced understandings of student-faculty interactions, such as how race and racism may play a role in accessing quality interactions with faculty for students of color $[13,14]$. Without a more nuanced and contextualized analysis that accounts for the university as a racialized organization [15], institutional leaders have often been made to believe that more frequent interactions with all faculty is always beneficial for all students.

This assumption that more frequent interactions with faculty is always beneficial for students can be problematic; however, as studies have shown, Black students often confront racially hostile environments within historically white institutions (HWIs) through their experiences with white faculty. For example, Johnson-Bailey, Valentine, Cervero, and Bowles' (2009) study found that generations of Black alumni who attended graduate school at a southern research university across five decades (1962-2003) experienced discrimination, forced representation, and stereotyping from white faculty members as routine parts of their graduate life [16]. Other scholars have also noted that Black students perceive white faculty as culturally insensitive, uninformed, and inexperienced regarding Black students at HWIs [17]. More recently, Haynes (2017) found that the pedagogical techniques of many white faculty "safeguard white supremacy and fuel the reproduction of racial hierarchies" [18] (p. 95). These studies illuminate the significance of examining student-faculty interactions in more nuanced and contextualized ways as interactions with white faculty often lead to interpersonal violence [19] for Black students. While prior studies have illuminated the often racist and tenuous interactions that Black students 
experience with white faculty [20-23], much less is known about which institutional contexts in relation to campus racial climate play a role in predicting negative interactions with white faculty [24]. Additionally, much remains unexplored about how an institution's history of exclusion, and in particular, its history of enslavement, may predict those cross-racial experiences.

Acknowledging and understanding a university's history of exclusion/inclusion are central to understanding its racial climate [24-26], yet very few empirical studies have actually examined how historical legacies of exclusion play a role in Black students' contemporary experiences, including their cross-racial interactions with white faculty. Given the rise in historical scholarship revealing how the enslavement of Black people played a critical role in the development of the U.S. system of higher education, where many white university faculty members at these institutions built their wealth on the slaving economy, owned enslaved persons, and brought them to university settings $[27,28]$, this study centers this racist violent history of one university in the South in the examination of Black students' interactions with white faculty. Specifically, the central purpose of this study is to understand whether a university's history of slavery plays a role in cross-racial interactions between Black students and white faculty, while accounting for students' background characteristics, perceptions of the institution and their experiences with contemporary forms of racism on campus.

\section{Literature Review}

\subsection{Contextualizing Black Students' Interactions with White Faculty}

While the benefits and desires to work and interact with faculty who are like oneself are important for Black students as Black faculty better understand their experiences and provide students with a system of support $[14,29,30]$, the racial demographics of university faculty in the U.S. largely remains white [31]. According to reports by ACE, there is a $-9.5 \%$ difference between the proportion of full-time faculty who are Black and the proportion of enrolled undergraduates who are Black, compared to a $+20.6 \%$ difference between the proportion of full-time faculty who are white and the proportion of enrolled undergraduates who are white [31,32]. Thus, if white students solely wanted to create homophilic relationships with white faculty, they have more opportunity and accessibility to do so with higher education's significant overrepresentation of white faculty. Conversely, Black students and other students of color are more likely to contend for time of a relatively small, overworked, and underappreciated faculty of color [33]. Therefore, at HWIs, Black faculty are minoritized in such a way that Black students often require interactions with and support from white faculty to succeed in college. In examining Black student-white faculty relationships at HWIs, it is important to acknowledge that Black students hold a disadvantaged position through both the student-faculty power dynamic and differences in racial power.

\subsection{Differences in the Type, Nature, and Quality of Interactions with Faculty}

Research has shown that the type, nature, and quality of interactions with faculty are not the same for all students, revealing differences based on gender [34-36], socioeconomic status (i.e., income, parental education, first-generation status) [36,37], and race/ethnicity [34,37-44]. With respect to gender, Kim and Sax (2009) found statistically significant gender differences on five of six different forms of student-faculty interactions [34]. They found that male students were more likely than female students to assist faculty with research as a volunteer or for pay and demonstrated more frequent interaction with faculty during lecture class sessions, whereas females were more likely to assist faculty with research for course credit and reported more frequent communication with faculty by email or in person. Differences were also found by social class and first-generation status, where students from upper-class families and with parents who attended college reported greater interactions with faculty across a number of different forms of student-faculty interaction [34]. Kim and Sax (2009) also show that female and non-first-generation students 
reported greater satisfaction with both advising by faculty on academic matters and access to faculty outside of class [34].

With respect to race/ethnicity, McCoy and colleagues (2015) found that white faculty frequently described their students from different racial groups as "academically inferior, less prepared, and less interested in pursuing research and graduate studies" [38] (p. 1), while often engaging racial/ethnic minoritized students from a distant and colorblind perspective. Additionally, studies have shown that Black students' academic ability was often met with skepticism by white faculty [23], and have often felt alienated and experienced racism both formally and informally when interacting with faculty at HWIs [39]. Furthermore, Solórzano et al. (2000) found that the racial microaggressions Black students experienced from white peers, staff, and faculty impacted the quality of those relationships and even discouraged some Black students from seeking out those relationships or taking advantage of campus services [40]. These findings suggest that accounting for students' experiences with racism are important when examining studentfaculty interactions $[37,40-44]$ as they can create a barrier when interacting with faculty, and as a result, can affect their academic achievement and college experience [45].

\subsection{The Salience of and Connections between Racial Microaggressions, Perceptions of the Institution, Stress Responses, and Student-Faculty Interactions}

A growing body of research has illuminated various elements connected to the nature of Black student interactions with white faculty, such as racial microaggressions, perceptions of the institution, and individual stress responses. Solórzano et al.'s (2000) early study of Black students at three historically white, research I universities revealed how experiences with racial microaggressions impacted students' academic and social life, their perception of their institution, and pushed many of them to the point of exit [40]. Additionally, racial microaggressions have been shown to contribute to Black males' race-related stress responses [46]. While previous research shows that the quality of Black students' interactions with white faculty is impacted when they experience microaggressions or stereotypes from white faculty $[23,40]$, it is unclear whether experiencing racial microaggressions in the college environment generally would predict negative interactions with white faculty, specifically. Cole's (2007) study, however, shows that students who experience more positive interracial interactions and participated in diversity functions during their college experience reported greater course-related faculty contact, advice and criticism from faculty, and establishment of a mentoring relationships with faculty, which suggests that cross-racial and diversity experiences in the general campus environment may predict the quality and nature of student-faculty interactions [37].

Moreover, recent research by Linder et al. (2019) has shown a connection between students' perceptions of the institutional administration addressing (or not addressing) the campus climate and their emotional and physical well-being [47]. Their study also reveals how those perceptions can also impact their interactions with faculty, especially when they challenge their inequitable institutional climates through activism [47]. Together, these findings related to racial microaggressions, perceptions of the institution addressing its campus climate, and race-related stress responses provide an important foundation for understanding how these various elements may play a role in understanding Black students' interactions with white faculty. However, prior studies highlighting the importance of students' experiences with racism in predicting student-faculty interactions have largely left an institution's racialized history under-explored. Furthermore, the rise in research illuminating university histories of slavery, while significant, largely remains historical, leaving out if and how these histories play a role in contemporary campus dynamics. To better understand how a university's history of enslavement may play a role in Black student interactions with white faculty, the following section explores the literature on visiting sites of enslavement and massive trauma. 


\subsection{Experiencing Historical Sites of Enslavement and Massive Trauma}

According to Keats (2005), when standing before the historical evidence of a massive trauma, people create a semblance of the historic event [48]. Although they did not witness or experience the event firsthand, the imaginative reconstruction impacts people greatly [48]. For example, Silverman et al.'s (1999) study showed that adolescents who participated in a memorial visit to concentration camps demonstrated symptoms of posttraumatic stress disorder [49].

Moreover, plantation and slave castle researchers have examined how visitors experience those former sites of enslavement and the uneven power relationships and trauma embedded in slavery heritage [50]. Prior research shows how former sites of enslavement are contested spaces in the construction and interpretation of slavery and Black life, where tour guides and materials either remember the enslaved or render them invisible [50,51]. In one study at a plantation museum in Louisiana, for example, many African American visitors indicated that there was not enough information about the enslaved and that their story was often glossed over [51]. Thus, the manner in which slavery is presented may impact individuals' learning, experience, and satisfaction.

Recent research has shown that attending college and living on a former site of enslavement, which are experiences that are far deeper and longer than visiting historic sites or museums, can impact Black students in several ways [52]. Specifically, Garibay, West, and Mathis (2020) found that Black students experienced stress responses (e.g., emotional, psychological, and behavioral) directly related to an institution's history of slavery [52]. However, it is unknown whether a university's history of slavery may play a role in other campus experiences critical to Black student success. Given that white university professors were often central figures in the enslavement of Black people on campuses with histories of slavery $[27,28]$, this study examines whether the racist violent enslavement history of an institution may play a role in predicting the quality of interactions that Black students have with white faculty on that campus.

\section{Theoretical Framework}

To examine the quality of Black student interactions with white faculty on a campus with historical ties to slavery, this study uses Hartman's $(1997,2007)$ concept of the "afterlife of slavery" [53,54]. Hartman (2007) asserts that slavery established a "ranking of life and worth that has yet to be undone" [54] (p. 4). She argues that the structural and perpetual racial violence, premature death, and ongoing limited access to education and health faced by Black people can be understood as the afterlife of slavery, where the historical memory of slavery is ever present and weighs heavily on Black life $[55,56]$. Black suffering and modes of Black subjection have repeated across spatiotemporal boundaries demonstrating how chattel slavery continues to shape contemporary Black being, the "afterlife of property" [57] (p. 15).

The afterlife of slavery connects directly to higher education as Black people were material goods for colleges in the Colonial Era and have continued to experience antiBlackness across eras of U.S. higher education history [19]. According to Dancy et al. (2018), higher education and the "academic model is still essentially a colonial one" [58] (p. 178) as Black students today face similar systemic configurations of anti-Black violence and trauma as those in the enslavement and Jim Crow era (e.g., microaggressions and tokenism) [59]. Additionally, Womack (2016) argues how the multigenerational oppression suffered by enslaved Africans and their descendants continues to affect the well-being of Black college students today as they fight to exist in their full humanity on college campuses [60].

We draw on the afterlife of slavery to understand internal dynamics of a campus with a history of slavery, specifically cross-racial student-faculty interactions between Black students and white professors, as white faculty members enslaved Black people and deemed them property on university campuses in the enslavement era $[19,27,28]$. White professors were also among the chief architects in crafting and legitimating the scholarship that supported slavery, the Black body's dehumanization, the rise of eugenics, and many 
anti-Black policies and practices $[27,28,61,62]$. Furthermore, as postsecondary institutions were forced to desegregate in the 1960s and enrollments among Black students increased, it was often white faculty that openly challenged Black students' right to attend college as well as their intellectual abilities [16,63]. Kendi (2012) notes even as the Civil Rights Movement significantly expanded Black enrollment in historically white institutions, universities continued to reproduce white superiority and Black inferiority in masked ways [64].

Hartman's (1997) notion of the "afterlife of slavery" opens avenues of connection between the multiple forms of marginalization and violence that Black students currently face and have been subject to throughout history by educational institutions $[57,58,65]$. For this study, we use the afterlife of slavery to connect an institution's history of racial violence with racial inequities in its present state, such as the minoritization of Black people among the faculty and student population, the ongoing experiences with racism faced by Black students and institutional responses to acts of racism, and the requirement for Black students to develop meaningful relationships with white faculty in majors where there are no Black faculty and the racial power dynamics embedded within those interactions. Furthermore, it allows us to explore the emotional impact of physical spaces and stories (told and untold) that are tied to slavery. Thus, in this study, we explore whether students' experiences with contemporary forms of racism (i.e., racial microaggressions) during college, perceptions of the institution addressing its racial inequity, and emotional responses to the institution's history of slavery predict negative interactions with white faculty for Black students on a campus with an enslavement history.

\section{Research Questions}

The following questions guided this study:

1. Do Black students' emotional responses to a university's history of slavery affect the quality of their interactions with white faculty?

2. Do Black students' emotional responses to a university's history of slavery mediate the effects of other variables (i.e., background characteristics, experiences with racial microaggressions, perception of the institution addressing its racial inequity) on the quality of interactions with faculty?

\section{Hypotheses}

While previous literature, in the aggregate, suggests the importance of racial microaggressions, perceptions of the institution's campus climate, and environment-related stress responses in understanding the quality and nature of student-faculty interactions, there is a dearth of studies that simultaneously examine the effects of these various elements on Black student-white faculty interactions. The statistical model hypothesizes that having experienced a greater amount of racial microaggressions has a direct effect on students perceptions of the institution addressing its racial inequity, their level of emotional response to the institution's history of slavery, and the quality of their interactions with white faculty (See Figure 1). The former two relationships are hypothesized because having direct experiences with racism, such as racial microaggressions and stereotypes, has been shown to predict individuals' environmental stress responses [46] and their perception of the institution [40]. Although prior research has shown that Black students often experience racial microaggressions from white faculty, which affects the quality of their interactions with white faculty $[23,40]$, there is no known study that has shown that experiencing racial microaggressions in the college environment generally would predict negative interactions white faculty, specifically. However, as described in the literature review, Cole (2007) found that students who experience more positive interracial interactions during college experience greater student-faculty interactions, suggesting that general cross-racial experiences can predict student-faculty interactions [37]. Thus, we test whether experiencing a greater amount of racial microaggressions in the college environment generally predicts negative interactions white faculty. Additionally, Black students' perceptions of the institution addressing its racial inequity is hypothesized to have a direct effect on their emotional 
response to the institution's history of slavery as well as quality of interactions with white faculty. These hypothesized relationships stem from literature that has shown how students' perceptions of the institutional administration addressing or not addressing the campus climate can impact their emotional and physical well-being as well as interactions with faculty, particularly when they challenge their inequitable institutional climates [47]. Lastly, we test the hypothesis that greater emotional responses to the institution's history of slavery will have a direct effect on the quality of interactions with white faculty as prior research has shown that white university professors were central figures in the enslavement of Black people on the campus in which this particular study took place.

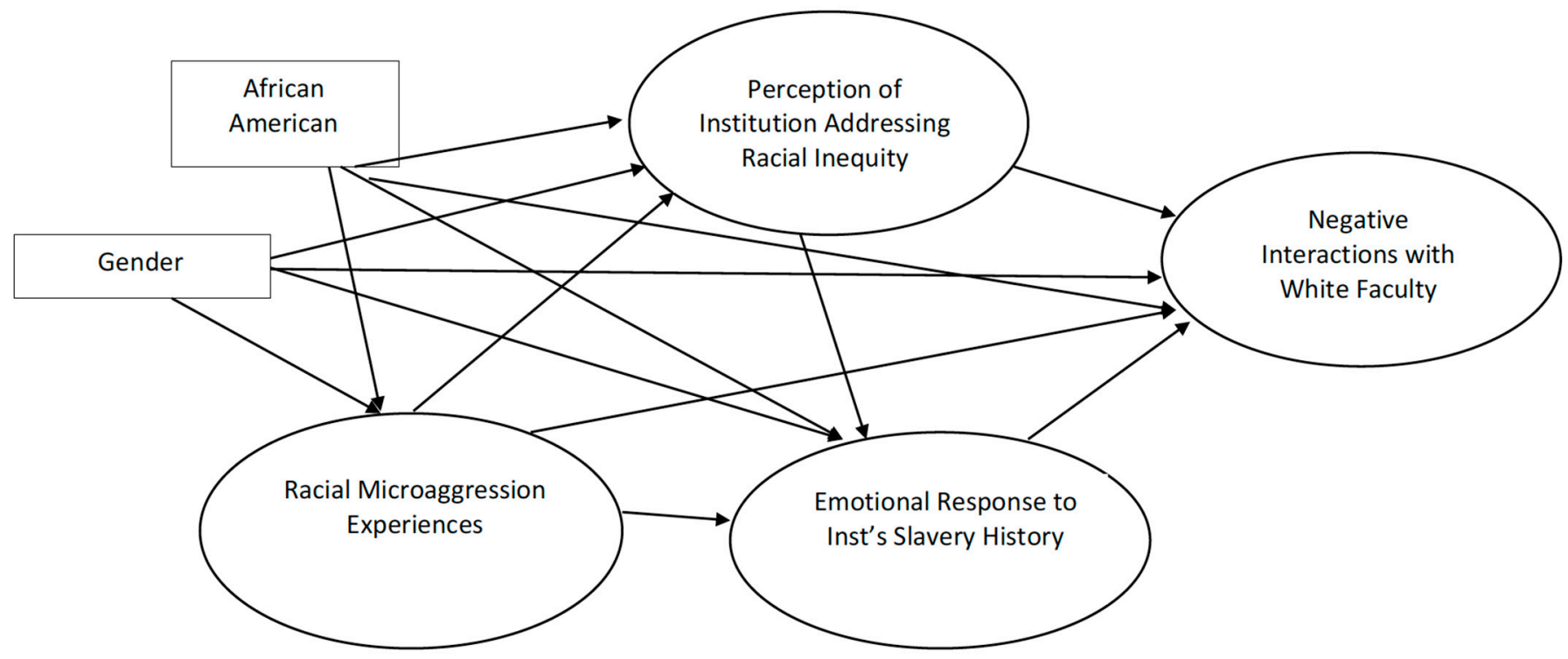

Figure 1. Hypothesized Model of Demographic and Racialized Experiences on Negative Interactions w/White Faculty.

Overall, the model posits that experiences with racial microaggressions, greater emotional responses to the institution's history of slavery, and student perceptions of the institution addressing its racial inequity directly shape Black student interactions with white faculty. Additionally, the model posits that racial microaggressions and perceptions of the institution indirectly influence Black students' interactions with white faculty via their direct effect on students' emotional response to the institution's slavery history. Racial microaggressions are also hypothesized to indirectly influence interactions with white faculty via their direct effect on students' perceptions of the institution, as well as their indirect effect on emotional response through perceptions of the institution. Furthermore, it is hypothesized that background characteristics (diaspora category: only African American, gender) will have direct and indirect effects on Black student-white faculty interactions.

\section{Critical Race Quantitative Inquiry}

This quantitative study is grounded on Critical Race Quantitative Inquiry, or QuantCrit, [66] to critically examine Black student experiences with one university's history of slavery and how that context may play a role in their interactions with faculty. In the vein of QuantCrit, we consider race a social construct that historically separates and oppresses particular groups [67]. Additionally, our survey instrument seeks to disrupt racial essentialism in higher education research [68] by understanding cross-sections within the African diaspora alongside other social characteristics [69], while also interrogating racial power dynamics at the institutional level.

The guiding principles of QuantCrit [66,67] and tenets of Critical Race Theory $[40,70]$ guided this study in the following ways. First, given that numbers are not neutral and that categories/groups are neither natural nor given [67], our work centers the egregious racist violence and institutional racism that is historically embedded on the campus and affects 
Black students (CRT tenet: centrality of race/racism). However, racism is a comlex and deeply rooted aspect of society that is not readily amenable to quantification [67]. Given the limitations of prior secondary datasets that either do not include data on racialized contexts or are limited in the operationalizations of racism that do not allow for the examination of the historical legacies of slavery, we, secondly, set out to develop our own survey instrument guided by the extant literature on how racism impacts people of color and the ongoing legacies of slavery [52,53]. Third, our study seeks to challenge the dominant mainstream ideologies that the legacy of slavery does not impact the experiences of Black students today and that universities were the cradle of a liberal society (CRT tenet: challenge to dominant ideology). Fourth, statistical analyses can play a role in struggles for social justice [67] and our study's goal is to illuminate Black students' specific experiences with the historical dimension of the campus to address these long legacies of injustice through university reparations (CRT tenet: commitment to social justice). Fifth, as quantitative data cannot "speak for itself" [67], our study recognizes the importance of legitimizing the personal experiences and histories of minoritized people when attempting to understand racial subordination in education (CRT tenet: centrality of experiential knowledge). In our study, experiential knowledge stems from the lived experiences of Black student participants and that of the researchers who through their collective experiences and understanding of racial issues through first-hand experience designed a survey with the intention of better illuminating the lived experiences of Black students at a university with a history of slavery. Sixth, our survey draws upon research from history, psychology, geography, higher education, and Black studies to empirically ground our discussion of the historical legacies of slavery in higher education and individual experiences with former sites of enslavement (CRT tenet: the interdisciplinary perspective). Lastly, we include the tenet of hegemony of whiteness [71] to contextualize how white supremacy is embedded in the university's history and contemporary dynamics, and, in turn, impacts Black students' lives.

\section{Positionality of the Researchers}

As espoused by Garcia et al. (2018), we provide information about our positionality to ground our social position, values, and epistemologies while using quantitative methods [66]. Each researcher has ancestors who were subjected to systems of unfree labor and has taught on a campus with a historical nexus to slavery. Our experiences, family histories, social identities, and epistemologies enabled us to understand the issues raised in this study with depth, and informed our lenses for approaching this study and interpreting the findings.

Juan Carlos Garibay identifies as a Chicano from a working-class Mexican immigrant family. He grew up in a predominantly Latinx segregated neighborhood of Los Angeles, which has historical ties to the American Civil War. He learned about the history of American slavery and historical spaces tied to U.S. slavery early in life as his neighborhood served as the military headquarters for the Union Army in Southern California. Additionally, his family immigrated from Las Zarquillas, Michoacán, whose residents including his ancestors were once subjected to peonage by owners of the Hacienda de Guaracha. Family oral histories taught him about the Spanish Colonial system of haciendas, slavery and peonage in Michoacán, and his great-grandfather's involvement in the community's resistance against the Guaracha hacendados (landowners). This resistance led to the intervention of then-Governor Lázaro Cárdenas in 1931, who endowed the land to the Las Zarquillas inhabitants [72]. It became one of Cárdenas's early models of hacienda fracturing through ejido formation before becoming president of Mexico and dismantling the oppressive hacienda system through national agrarian reform. This family history, growing up in a segregated community of color with parents and grandparents who experienced anti-Mexican immigrant attitudes, and teaching at HWIs taught him the multiple ways racism manifests in society and education.

Christopher Mathis identifies as a Black American whose family has direct ancestral ties to enslaved people in South Carolina. In fact, his great-grandfather was born shortly 
after slavery at the height of the Jim Crow South, but later taught himself how to both read and write and subsequently attended an HBCU, now known as Oakwood University. Mathis spent a considerable amount of time in his family's hometown of Johnston, S.C., on approximately 130 acres, the same land his great-grandfather purchased from white plantation owners. Additionally, all of his university training was on either former slave plantations where formerly enslaved people built the campus or where the university itself enslaved people. Learning and teaching in the same spaces where generations of Black Americans made such grave sacrifices has taught him both the significant factors of racism and the perseverance, tenacity, and diligence Black Americans possess in order to succeed in racialized spaces.

\section{Methods}

\subsection{Data and Sample}

The data used for this study were collected using the preliminary version of the Survey of Black Student Experiences at Universities with Historical Relationships to Slavery (SBSE) at a public research university in the South with documented evidence of having a history of slavery. The university has approximately 17,000 undergraduate students, and Black students only make up approximately $7 \%$ of the entire population. Additionally, Black faculty represent approximately $4 \%$ of the faculty, while white faculty make up over $70 \%$. This pilot study collected survey data from undergraduate students of African descent to explore relationships and establish a proof of concept. The SBSE was designed to capture the various ways a university's history of slavery may relate to many aspects of campus life, including learning, engagement, sense of belonging, among many others. Items on the survey were grounded on the extant literature on Black students at HWIs, including racial microaggressions, racial battle fatigue, and campus racial climate $[24,25,40,46,73]$. One education professor and one higher education administrator from the university, both with expertise in the experiences of Black students, evaluated the face validity of the survey items. Additionally, one faculty member with expertise in survey methodology assessed the suitability of the item sets for scale construction. Only minor revisions were needed, and these experts helped to provide important validity evidence for the instrument based on test content [74].

IRB approval to collect data was obtained in Spring 2018. The online survey was administered through Qualtrics between October 2018 and January 2019 to students through several avenues: (1) one Black student organization's listserv, (2) posts on a newsletter from an office dedicated to Black student affairs, (3) direct emails to students collected from a course known to have a large number of Black students enrolled, and (4) direct emails to a random sample of students in a second Black student organization. The sample for this study includes 92 undergraduate students of African descent, which represented approximately $8.5 \%$ of the total number of Black undergraduate students at the university during that year. Over $43 \%$ of the sample were first years, $9.8 \%$ were second years, $20.7 \%$ were third years, and $26.1 \%$ were fourth years. In comparison to the full population of undergraduates at the institution who identify as Black/African American, our sample was significantly overrepresented by female and fourth year students, slightly overrepresented by first year students, and underrepresented by male, second, and third year students.

\subsection{Variables}

\subsubsection{Primary Endogenous Variable: Negative Interactions with White Faculty}

Given that Black students often experience discrimination, stereotyping, and interpersonal violence from white faculty $[16,19]$, the primary endogenous variable in this study was a latent variable called negative interactions with white faculty, which was comprised of three items: (a) whether students "had guarded, cautious interactions with white faculty," (b) "had tense, somewhat hostile interactions with white faculty," and (c) whether students felt "white faculty empowered [them] to learn [at this institution] (reverse coded)." The first two items were measured on a scale from $1=$ not at all to $3=$ frequently, while the third 
item when reverse coded was measured on a scale from $1=$ strongly agree to $4=$ strongly disagree. While this latent variable is called "negative interactions with white faculty" for brevity, it captures a sense of hostile, tense, and non-empowering interactions with white faculty, which are negative qualitatively and opposite to positive cross-race mentoring models as explained by Reddick and Pritchett (2015) [75]. The Cronbach's alpha for the negative interactions with white faculty factor was $\alpha=0.633$, which provides important validity evidence based on internal structure [74]. Table 1 includes variable descriptions and their coding schemes for all of the variables used in statistical model, including alpha coefficients for the latent variables.

Table 1. Key Variable Descriptions.

\begin{tabular}{|c|c|c|}
\hline Measures & Description & Coding \\
\hline $\begin{array}{l}\text { Negative Interactions with White Faculty } \\
(\alpha=0.633)\end{array}$ & $\begin{array}{l}\text { Latent variable made up of the following items: (1) had } \\
\text { guarded, cautious interactions with white faculty, (2) had } \\
\text { tense, somewhat hostile interactions with white faculty, } \\
\text { (3) white faculty empower me to learn here (reverse coded) }\end{array}$ & Continuous \\
\hline African American Only (Ref: All other Black) & Whether the student identifies as only African American & $1=$ Yes, $0=$ No \\
\hline Cisgender Man & Whether the student identifies as Cisman or not & $1=$ Yes, $0=$ No \\
\hline Racial Microaggressions $(\alpha=0.841)$ & $\begin{array}{l}\text { Latent variable made up of the following items: } \\
\text { (1) non-verbal slights related to your race/ethnicity, } \\
\text { (2) poorer service because of your race/ethnicity, } \\
\text { (3) perceived to be less intelligent because of your } \\
\text { race/ethnicity, (4) perceived to be dishonest because of } \\
\text { your race/ethnicity, (5) verbal insults related to your } \\
\text { race/ethnicity }\end{array}$ & Continuous \\
\hline $\begin{array}{l}\text { Perception of Inst Addressing Racial Inequity } \\
(\alpha=0.714)\end{array}$ & $\begin{array}{l}\text { Latent variable made up of the following items: (1) I feel } \\
\text { confident in this inst's leadership response to its } \\
\text { involvement with slavery, (2) this inst is committed to } \\
\text { developing an environment that is conducive to the } \\
\text { success of students of color, (3) this inst's response to bias } \\
\text { incidents has made me feel at ease }\end{array}$ & Continuous \\
\hline $\begin{array}{l}\text { Emotional Response to Inst's Enslavement } \\
\text { History }(\alpha=0.906)\end{array}$ & $\begin{array}{l}\text { Latent variable made up of the following items: (1) I often } \\
\text { feel resentment towards this inst because of its } \\
\text { involvement with slavery, (2) I often feel anger towards } \\
\text { this inst because of its involvement with slavery, (3) I often } \\
\text { feel frustrated because of this inst's involvement with } \\
\text { slavery, (4) I often feel helpless because of this inst's } \\
\text { involvement with slavery, (5) I often feel depressed } \\
\text { because of this inst's involvement with slavery }\end{array}$ & Continuous \\
\hline
\end{tabular}

\subsubsection{Mediating Variables}

The mediating variables included in the statistical model were three latent variables designed to capture students' contemporary experience with racism on campus, their perceptions of the institution, and experience with the university's violent racist history of slavery as prior research has shown racialized experiences [14,76,77], cross-racial interactions, and racial microaggressions connect to the quality and frequency of student-faculty interactions [37,40]. First, we included students' experiences with racial microaggressions $(\alpha=0.841)$, which was made up of five items (see Table 1$)$. Students were asked how often they experienced each of those items during their time at the institution measured on a five-point ordinal scale $(1=$ never to $5=$ very often $)$. Second, we developed a factor called "perceptions of the institution addressing its racial inequity" ( $\alpha=0.714)$ using three items on the SBSE (see Table 1), each measured on a four-point Likert scale $(1=$ strongly disagree to $4=$ strongly agree). 
Lastly, to capture whether the institution's legacy of slavery may play a role in Black students' interactions with white faculty, we included a factor examining Black students' emotional $(\alpha=0.906)$ stress response to the university's history of slavery [52], which included the five items listed in Table 1. Each item was measured on a four-point Likert scale $(1=$ strongly disagree to $4=$ strongly agree). For the mediating variables, higher values on the three factors suggest more experiences with racial microaggressions at the university, more positive perceptions of the institution addressing its racial inequity, and greater emotional stress response to the university's history of slavery, respectively. The correlations between the latent variables are provided in the Appendix A.

\subsubsection{Exogenous Variables}

The final model included two individual background characteristics in this study. Given the importance of examining the varying experiences within the Black student population $[78,79]$ and this study's focus on American higher education institution's nexus to slavery, the model included a categorical variable for students who identified as only African American (compared to all other Black students). The category of "all other Black" included those who identified as only African (12\% of total), two or more groups of African descent $(8.7 \%$ of total), and Black with other groups (18.5\% of total). Gender was also included as a predictor variable as some studies have found disparate results between men and women students in their interactions with faculty [12,34-36]. In this study, it is essential to note that one student identified as genderqueer/gender non-conforming, one student identified as "difference," 68 identified as cisgender women, and 21 identified as cisgender men. Given that only two trans* students were in this sample, we included a categorical variable to compare cisgender men $(1=$ yes, $0=$ no) to cisgender women and the trans* students as we did not want to delete the trans* students' valued participation (See Table 2 for descriptive statistics of the sample).

Table 2. Descriptive Statistics $(n=92)$.

\begin{tabular}{|c|c|c|c|c|c|}
\hline Variables & $\%$ Missing & Mean & SD & Min & Max \\
\hline $\begin{array}{l}\text { Negative Interactions with } \\
\text { White Faculty }\end{array}$ & 0 & 0.000 & 0.819 & -0.98 & 2.39 \\
\hline Racial Microaggressions & 1.1 & -0.009 & 0.995 & -1.39 & 2.702 \\
\hline $\begin{array}{l}\text { Perception of Inst Addressing } \\
\text { Racial Inequity }\end{array}$ & 2.2 & 0.021 & 0.998 & -2.03 & 2.21 \\
\hline $\begin{array}{l}\text { Emotional Response to Inst's } \\
\text { Enslavement History }\end{array}$ & 0 & 0.013 & 1.001 & -1.36 & 2.23 \\
\hline Categorical Variables & $\%$ Missing & \multicolumn{2}{|c|}{ Categories } & $\mathbf{n}$ & $\%$ \\
\hline \multirow{2}{*}{$\begin{array}{l}\text { African American Only } \\
\text { (Ref: All other Black) }\end{array}$} & \multirow[t]{2}{*}{0} & \multicolumn{2}{|c|}{ Yes } & 56 & 60.9 \\
\hline & & \multicolumn{2}{|c|}{ No } & 36 & 39.1 \\
\hline \multirow[t]{2}{*}{ Cisgender Man } & 0 & \multicolumn{2}{|c|}{ Yes } & 21 & 22.8 \\
\hline & & \multicolumn{2}{|c|}{ No } & 71 & 77.2 \\
\hline
\end{tabular}

\subsection{Analysis}

Data analyses were conducted in two stages. First, to develop the conceptually supported factors in this study, we used principal axis factoring with varimax rotation to identify the items that represent each latent variable and reliability analyses using tests of internal consistency (see Table 2). Second, we constructed a structural equation model in the Stata/SE 17.0 software program, and utilized maximum likelihood with missing values to preserve the full dataset as there was very minimal data missing in the sample [80]. After running the initial model, analysis of goodness of fit revealed the model did not fit the data well. We then used theoretical presuppositions and modification indices to conduct model-building [81]. We added paths between error terms within the racial 
microaggressions factor and emotional response to slavery history, respectively, which resulted in a substantial improvement to model fit.

\section{Limitations}

This study is limited in several ways. First, the sample used in this study is obtained from only one university with a history of slavery and the sample is not necessarily representative of the institution, thus generalizations of the findings cannot be made beyond this study's sample. Second, we utilized multiple sampling strategies, which may lead to sampling bias for the current study. Third, this study's data were based on students' self-reported experiences with white faculty, which is regarded as a limitation [82]. Fourth, given the small sample size, we were constrained in the number of variables used to make up our models. While we captured essential variables in the model based on the extant literature and theory, the list is not exhaustive, and other confounding variables may need to be included to better examine cross-racial relationships between Black students and white faculty. For example, this study's data did not capture any pre-college educational experiences with white teachers, which may predict Black students' dynamics with white college professors. Fifth, given that the data for this study are cross-sectional, collected at one time point, our results should be interpreted accordingly as exhibiting an association rather than a causal inference. Additionally, particular hypothesized relationships in this preliminary model may also be potentially hypothesized in opposite directions, but given that the data are cross-sectional this study is limited in being able to test what factor may precede the other. We stress that future research in this area collect longitudinal data to more fully examine such hypothesized relationships. While these limitations are noteworthy, this exploratory study contributes to our preliminary understanding of how a university's history of slavery may play a role in contemporary Black student-white faculty interactions.

\section{Results}

Table 3 shows the model fit results of the final structural equation model. We used the following key indices of fit: Root Mean Square Error of Approximation (RMSEA), Comparative Fit Index (CFI), and Tucker-Lewis Index (TLI). For the RMSEA, Hu and Bentler (1999) [83] suggested a value close to 0.06 to indicate good fit between the hypothesized model and the observed data. However, $\mathrm{Hu}$ and Bentler (1999) cautioned that when the sample size is small, such as in this study, a 0.06 cutoff value for the RMSEA, tends to over-reject true population models. Browne and Cudeck (1993) indicated that values as high as 0.08 represent reasonable errors of approximation in the population, indicating fair fit $[84,85]$. For the CFI and TFI, values above 0.90 were taken to indicate an acceptable fit $[86,87]$. Each of the three tests suggest that the final model was a "fair" or "acceptable" fit for the data as the model produced a CFI of 0.93, a TLI of 0.91, and a RMSEA of 0.07.

Table 3. Model Fit Results ( $\mathrm{n}=92)$.

\begin{tabular}{|c|c|c|c|c|}
\hline Chi-sq, ms & Chi-sq, bs & CFI & TLI & RMSEA \\
\hline $167.092\left(^{* *}\right)$ & $917.7\left(^{* * *}\right)$ & 0.93 & 0.91 & 0.07 \\
\hline
\end{tabular}

(b) RMSEA less than 0.08 (Browne and Cudeck, 1993; Byrne, 2006).

Table 4 presents the standardized path coefficients for the direct, total indirect, and total effects for the final SEM, as well as the equation-level goodness of fit results. The standardized path coefficients represent the standard deviation change in the endogenous variable corresponding to a one standard deviation change in the predictor variable when all other variables in the model are held constant. Those results are also displayed in Figure 2. The models accounted for $7.44 \%$ of the variance in racial microaggressions, $39.18 \%$ of the variance in slavery history emotional response, $66.85 \%$ of the variance in 
perception of the institution addressing its racial inequity, and $88.05 \%$ of the variance in negative interactions with white faculty.

Table 4. Structural Equation Modeling Results: Standardized Path Coefficients for Direct, Total Indirect, and Total Effects.

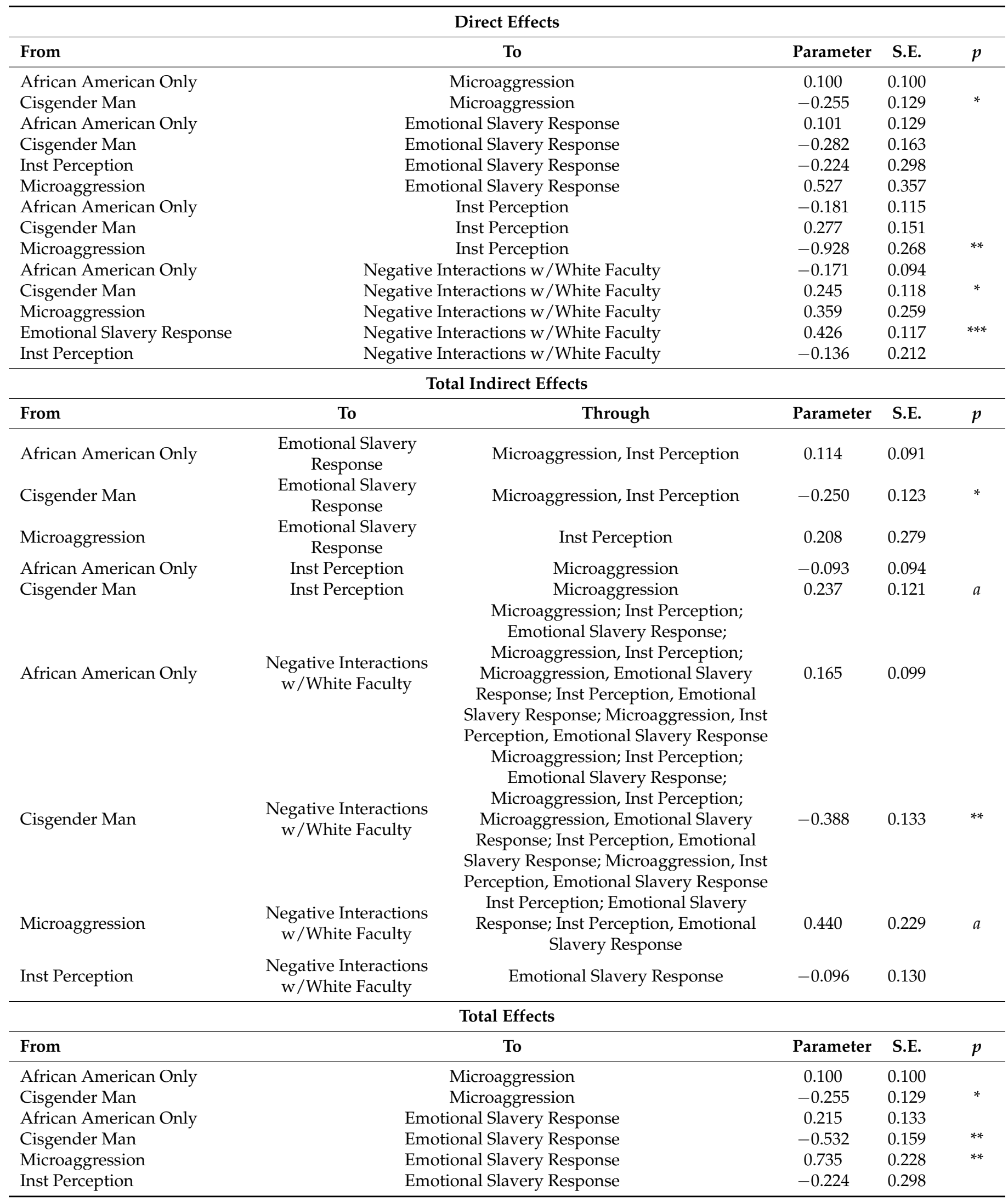


Table 4. Cont.

\begin{tabular}{|c|c|c|c|c|}
\hline \multicolumn{5}{|c|}{ Total Effects } \\
\hline From & To & Parameter & S.E. & $p$ \\
\hline African American Only & Inst Perception & -0.274 & 0.136 & * \\
\hline Cisgender Man & Inst Perception & 0.513 & 0.176 & ** \\
\hline Microaggression & Inst Perception & -0.928 & 0.268 & ** \\
\hline African American Only & Negative Interactions w/White Faculty & -0.006 & 0.119 & \\
\hline Cisgender Man & Negative Interactions w/White Faculty & -0.144 & 0.136 & \\
\hline Microaggression & Negative Interactions $\mathrm{w} /$ White Faculty & 0.799 & 0.238 & $* *$ \\
\hline Inst Perception & Negative Interactions w/White Faculty & -0.232 & 0.249 & \\
\hline Emotional Slavery Response & Negative Interactions w/White Faculty & 0.426 & 0.117 & $* * *$ \\
\hline Equation-Level Goodness of Fit & & $\mathbf{R} 2$ & & \\
\hline Microaggression & & 0.0744 & & \\
\hline Emotional Slavery Response & & 0.3918 & & \\
\hline Inst Perception & & 0.6685 & & \\
\hline Negative Interactions $\mathrm{w} /$ White Faculty & & 0.8805 & & \\
\hline
\end{tabular}

Note. ${ }^{* * *} p<0.001,{ }^{* *} p<0.01,{ }^{*} p<0.05, a: 0.05<p<0.06$

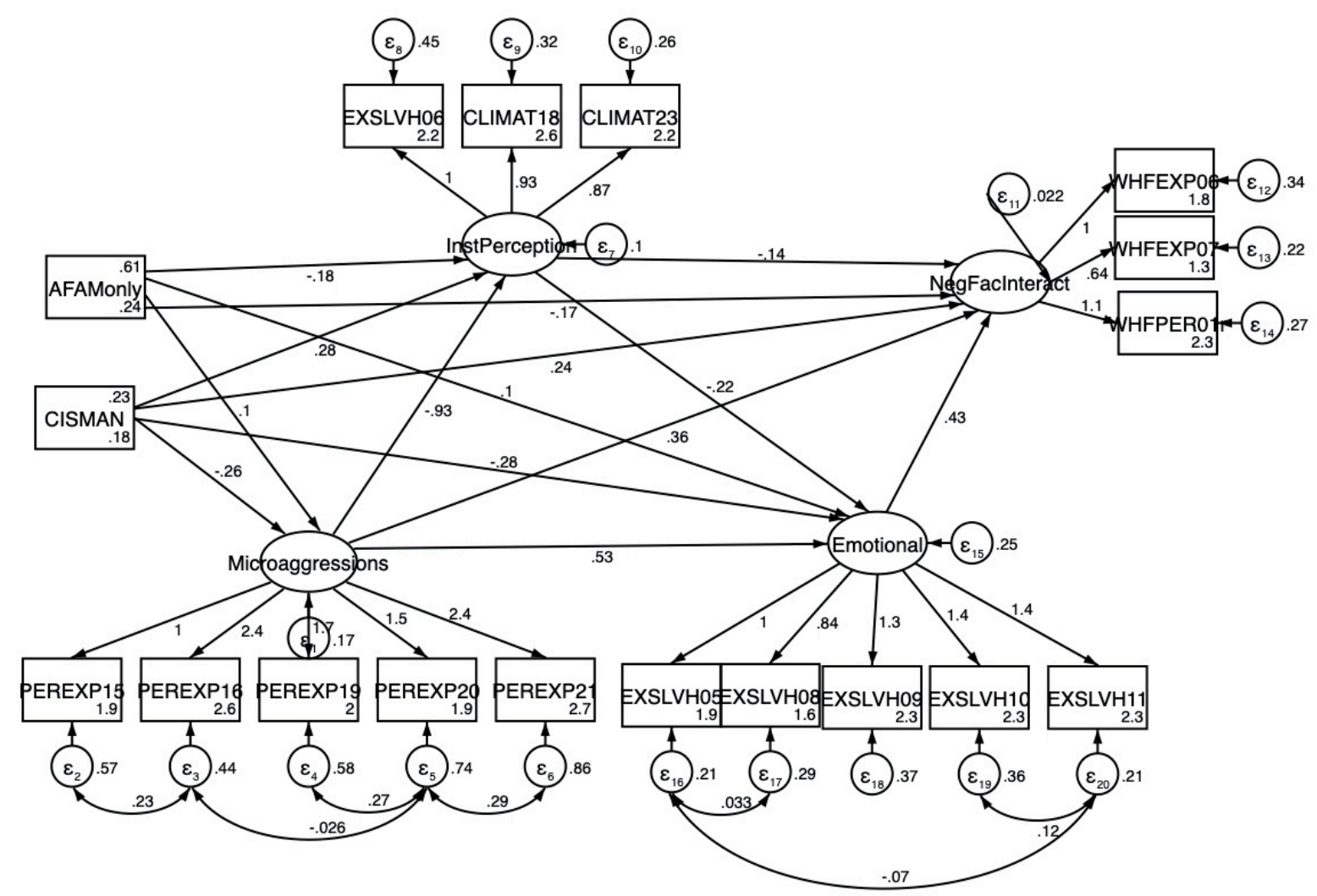

Figure 2. Final Structural Equation Model with Standardized Path Coefficients.

\subsection{Key Direct Effects}

Two variables had statistically significant direct effects on greater negative interactions with white faculty. Students who identified as cismen $(b=0.245, p<0.05)$ and had greater emotional stress responses to the university's history of slavery $(b=0.426, p<0.001)$ each had a direct and positive effect on negative interactions with white faculty. Additionally, identifying as a cisgender man had a direct negative effect $(b=-0.255, p<0.05)$ on experiencing greater racial microaggressions at the university, while experiencing greater racial microaggressions at the university had a direct negative effect $(b=-0.928, p<0.01)$ on students' perception of the institution addressing its racial inequity. 


\subsection{Total Indirect Effects}

The Stata program reports total indirect effects, which is the sum of each indirect effect between a predictor and an endogenous variable. There were two total indirect effects that were statistically significant in the final structural equation model. Identifying as a cisgender man had a total indirect effect that was negative on both negative interactions with white faculty $(b=-0.388, p<0.01)$ and emotional responses to the university's history of slavery $(b=-0.250, p<0.05)$.

\subsection{Total Effects}

The total effects are the sum of the direct and indirect effects. Results demonstrate that two variables had total effects on negative interactions with white faculty that were statistically significant. Specifically, having greater experiences with racial microaggressions during their time at the institution $(b=0.799, p<0.01)$ and greater emotional responses to the university's history of slavery $(b=0.426, p<0.001)$ each had total effects on negative interactions with white faculty that were statistically significant.

There were also total effects that were statistically significant between racial microaggressions $(b=0.735, p<0.01)$ and emotional responses to the institution's history of slavery, and cisgender man $(b=-0.532, p<0.01)$ and emotional responses to the institution's history of slavery. Additionally, the results also show total effects that were statistically significant between identifying as only African American $(b=-0.274, p<0.05)$, cisgender $\operatorname{man}(b=0.513, p<0.01)$, and greater experiences with racial microaggressions $(b=-0.928$, $p<0.01)$ on perception of the institution addressing its racial inequity, respectively.

\section{Discussion}

Having access to frequent and quality interactions with faculty is essential for students of color and their success [41]. Given that white professors are significantly overrepresented among faculty in the U.S., a direct examination of Black student interactions with white faculty can help illuminate important dynamics that need to be addressed to ensure quality cross-racial student-faculty interactions for Black students. Although scholars have highlighted the significance of racialized experiences [14] on student-faculty interactions, as well as a university's historical legacies of exclusion on the campus racial climate [24-26], research on whether a university's history of slavery plays a role in Black student-white faculty interactions has been underdeveloped. Using Hartman's notion of the afterlife of slavery, this exploratory study's findings provides evidence to support that Black student interactions with white faculty may be understood through a lens that recognizes the vestiges of slavery on university campuses, and bridges the historical legacies of exclusion of campus racial climate research [24-26] with historical research on university histories of slavery $[27,28]$, which is not explicit in prior campus climate frameworks.

The afterlife of slavery suggests that the continuing social, economic, health, and educational inequities faced by Black people are the direct result of slavery and antiBlack racism $[53,54]$. In this study, an institution's racist violent history of slavery plays a role in understanding the quality of Black students' interactions with white faculty. Specifically, having greater emotional responses to the institution's history of slavery has a statistically significant direct association with negative interactions with white faculty. This finding is important because it begins to expand our understanding of the educational inequities faced by Black college students on this particular campus as the afterlife of a university's history of slavery. The finding also expands research showing how racism continues to manifest over the course of institutions' histories despite some progress [16] by extending our understanding of how students' experiences with the historical legacy of exclusion on a campus may shape contemporary racial dynamics between Black students and white faculty.

Additionally, the ongoing and perpetual experiences with anti-Black racism, such as racial microaggressions, connect to the continuing legacies of slavery [52]. Indeed, greater experiences with racial microaggressions at the institution had total positive associations 
with students' emotional responses to the institution's slavery history. Thus, students who experienced racial microaggressions had greater emotional stress responses to the university's history of slavery. In this study, greater experiences with racial microaggressions at the institution also had total positive associations with negative interactions with white faculty, which connects with prior literature on the importance of examining experiences with racism when investigating cross-racial relationships between Black students and white faculty [14], and suggests a possible carryover effect of racial microaggression experiences in the college environment to specific cross-racial experiences. These findings also provide further evidence on the significance of racial microaggressions in Black students' college experiences and factors that have a direct impact on their success [40,46], illuminating the connection between contemporary experiences of anti-Black racism, the afterlife of slavery on campus, and cross-racial interactions between Black students and white faculty.

Lastly, we found that several paths between background characteristics and endogenous variables were statistically significant. Cisgender men were found to have significantly lower emotional responses to the institution's slavery history (indirect and total effects) and greater perceptions of the institution addressing its racial inequity (total effect). However, a more complex relationship between gender and negative interactions with white faculty was found as cisgender men had greater negative interactions with white faculty (direct effect), but an indirect negative association with negative interactions with white faculty through mediating variables in the model, suggesting the importance and need to better understand how different forms of oppression may affect Black cis-women, trans*, and cis-men differently in their interactions with white faculty and overall college experience. Additionally, differences between students who identified as only African American compared to other Black students were found on their perception of the institution addressing its racial inequity (total effect), which connects to research by Mwangi and Fries Britt (2015) [78], who found that Black immigrant students are less likely to assume negative incidents occurring on campus based on race or racism. Together, these findings in the statistical model related to background characteristics show the significance of examining within-group differences for students of African descent $[78,79]$ to develop deeper and more nuanced understandings of Black college student success.

\section{Implications}

This preliminary study has implications for research, policy, and practice. First, an increasing number of universities are beginning to grapple with their histories of slavery and some have already proposed and/or engaged in reparative efforts. Although Black students tend to support more comprehensive forms [88], prior forms of higher education reparations have largely been symbolic [89], which do little to change the structural conditions negatively shaping Black students' experiences and outcomes [90,91]. Furthermore, largely ignored is the continual impact of the institution's enslavement history on Black students' college experiences and success [52,89], including their relationships with faculty. This study begins to illuminate how an institution's history of slavery along with students' experiences with racial microaggressions on campus play important roles in Black students' relationships with white faculty. Thus, if institutions seek to create equitable, racially-just college success experiences for Black students, institutional leaders and educators must not solely address contemporary forms of anti-Blackness and a university's history of slavery separately, but also recognize that an institution's anti-Black violent history connect to current racialized experiences and racial inequities.

Second, to better develop initiatives aimed at engendering supportive student-faculty relationships for Black students, institutions should assess cross-racial and homophilic student-faculty interactions as opposed to solely examining student-faculty interactions generally. This would allow institutions to better understand the racial dynamics within a critical area of student success. Utilizing such data along with investments in faculty training that promote awareness of the institution's history and Black degradation may go 
a long way in increasing institutional capacity to build racially-just supportive relationships between all faculty and students of African descent at institutions with histories of slavery

Third, while developing all faculty members' capacity to develop meaningful, supportive, and mentoring relationships with Black students is critical, institutional leaders should continue to work to increase the number of, support, and retain Black faculty. The minoritization of Black faculty can be understood through a historical lens illuminating higher education's history of anti-Blackness [19,58], and without major improvements Black students and faculty alike are placed at a significant disadvantage which can continue to impact the racial climate and racial power dynamics on campus. When the compositional diversity among faculty reflects the student diversity, campuses tend to enjoy more welcoming and inclusive environments [92] and students who seek homophilic relationships are more likely to find them without placing extra burdens on faculty within those demographic groups. Therefore, it essential that institutions contend with present-day structures that stifle Black access and success to faculty careers.

Lastly, this preliminary study on one campus with a history of slavery provides evidence of how background characteristics, particularly gender, may play a role for Black students in accessing quality college experiences that are foundational to student success. As we expand this work, we will continue to refine and develop more sophisticated models focused on cross-racial student-faculty interactions utilizing data from multiple institutions with enslavement histories, while accounting for the diversity among Black students. This will allow us to learn more about how different members of the diaspora experience relationships with faculty, whether such experiences vary across institutions, and, if so, what contexts help to explain this variation. This research will help to develop more representative and nuanced understandings of cross-racial interactions between Black students and white faculty within and across institutions with histories of slavery.

Author Contributions: Conceptualization, J.C.G. and C.M.; methodology, J.C.G.; formal analysis, J.C.G.; literature review, J.C.G. and C.M.; theory, J.C.G. and C.M.; writing-original draft preparation, J.C.G. and C.M.; writing-review and editing, J.C.G.; project administration, J.C.G.; funding acquisition, J.C.G. All authors have read and agreed to the published version of the manuscript.

Funding: This research received no external funding. It was supported by a faculty seed grant.

Institutional Review Board Statement: The study was conducted according to the guidelines of the Declaration of Helsinki, and approved by the Institutional Review Board of the University of Virginia (current protocol code 2468 and 10/27/19, originally \#2018-0153 approved 04/2018).

Informed Consent Statement: Informed consent was obtained from all subjects involved in the study.

Data Availability Statement: Not applicable.

Acknowledgments: Not applicable.

Conflicts of Interest: The authors declare no conflict of interest. The funder had no role in the design of the study; in the collection, analyses, or interpretation of data; in the writing of the manuscript, or in the decision to publish the results.

\section{Appendix A}

Table 1. Correlations between Latent Variables.

\begin{tabular}{|c|c|c|c|c|}
\hline Variables & $\begin{array}{c}\text { Emotional Response } \\
\text { to Universities } \\
\text { History of Slavery }\end{array}$ & $\begin{array}{l}\text { Perception of Inst } \\
\text { Addressing Its } \\
\text { Racial Inequity }\end{array}$ & $\begin{array}{l}\text { Racial Micro- } \\
\text { Aggressions }\end{array}$ & $\begin{array}{c}\text { Negative } \\
\text { Interactions with } \\
\text { White Faculty }\end{array}$ \\
\hline $\begin{array}{l}\text { Emotional Response to Universities History } \\
\text { of Slavery }\end{array}$ & 1 & & & \\
\hline Perception of Inst Addressing Its Racial Inequity & $-0.425^{* *}$ & 1 & & \\
\hline Racial Microaggressions & $0.464 * *$ & $-0.531 * *$ & 1 & \\
\hline Negative Interactions with White Faculty & 0.530 ** & $-0.352 * *$ & $0.507^{* *}$ & 1 \\
\hline
\end{tabular}




\section{References}

1. Astin, A.W. What Matters in College? Four Critical Years Revisited; Jossey-Bass: San Francisco, CA, USA, 1993.

2. Bean, J.P. Interaction effects based on class level in an exploratory model of college student dropout syndrome. Am. Educ. Res. J. 1985, 22, 35-64. [CrossRef]

3. Cabrera, A.F.; Colbeck, C.L.; Terenzini, P.T. Developing performance indicators for assessing classroom teaching practices and student learning: The case of Engineering. Res. High. Educ. 2001, 42, 327-352. [CrossRef]

4. Campbell, T.A.; Campbell, D.E. Faculty/student mentor program: Effects on academic performance and retention. Res. High. Educ. 1997, 38, 727-742.

5. Kuh, G.D. The other curriculum: Out-of-class experiences associated with student learning and personal development. J. High Educ. 1995, 66, 123-155. [CrossRef]

6. Lamport, M.A. Student-faculty interaction and the effect on college student outcomes: A review of the literature. Adolescence 1993, 28, 971-990. [PubMed]

7. Pascarella, E.T. Student-faculty informal contact and college outcomes. Rev. Educ. Res. 1980, 50, 545-595. [CrossRef]

8. Pascarella, E.T. Students' affective development within the college environment. J. High. Educ. 1985, 56, 640-663. [CrossRef]

9. Pascarella, E.T.; Terenzini, P.T. Informal interaction with faculty and freshman ratings of academic and nonacademic experience of college. J. Educ. Res. 1976, 70, 35-41. [CrossRef]

10. Pascarella, E.T.; Terenzini, P.T. How College Affects Students: A Third Decade of Research; Jossey-Bass: San Francisco, CA, USA, 2005.

11. Strauss, L.C.; Terenzini, P.T. The effects of students in- and out-of-class experiences on their analytical and group skills: A study of engineering education. Res. High. Educ. 2007, 48, 967-992. [CrossRef]

12. Kuh, G.D.; Hu, S. The effects of student-faculty interaction in the 1990s. Rev. High. Educ. 2001, 24, 309-332. [CrossRef]

13. Cohen, G.L.; Steele, C.M. A Barrier of Mistrust: How Negative Stereotypes Affect Cross-Race Mentoring. In Improving Academic Achievement; Aronson, J., Ed.; Academic Press: Oxford, UK, 2002; pp. 303-327.

14. Cole, D.; Griffin, K.A. Advancing the Study of Student-Faculty Interaction: A Focus on Diverse Students and Faculty. In Higher Education: Handbook of Theory and Research; Springer: Dordrecht, The Netherlands, 2013; pp. 561-611.

15. Ray, V. A theory of racialized organizations. Am. Sociol. Rev. 2019, 84, 26-53. [CrossRef]

16. Johnson-Bailey, J.; Valentine, T.; Cervero, R.M.; Bowles, T.A. Rooted in the soil: The social experiences of Black graduate students at a southern research university. J. High. Educ. 2009, 80, 178-203. [CrossRef]

17. Schwitzer, A.M.; Griffin, O.T.; Ancis, J.R.; Thomas, C.R. Social adjustment experiences of African American college students. J. Couns. Dev. 1999, 77, 189-197. [CrossRef]

18. Haynes, C. Dismantling the white supremacy embedded in our classrooms: White faculty in pursuit of more equitable educational outcomes. Int. J. Teach. Learn. High. Educ. 2017, 29, 87-107.

19. Mustaffa, J.B. Mapping violence, naming life: A history of anti-Black oppression in the higher education system. Int. J. Qual. Stud. Educ. 2017, 30, 711-727. [CrossRef]

20. Ancis, J.R.; Sedlacek, W.E.; Mohr, J.J. Student perceptions of campus cultural climate by race. J. Couns. Dev. 2000, 78, 180-185. [CrossRef]

21. Cokley, K.; Rosales, R.; Komarraju, M.; Shen, F.; Pickett, R.; Patel, N. A new scale for assessing the quality of student-professor interactions. J. Profr. 2006, 1, 53-67.

22. Eimers, M.T.; Pike, G.R. Minority and nonminority adjustment to college: Differences or similarities? Res. High. Educ. 1997, 38, 77-97. [CrossRef]

23. Fries-Britt, S.L.; Turner, B. Facing stereotypes: A case study of Black students on a White campus. J. Coll. Stud. Dev. 2001, 42, 420-429.

24. Hurtado, S.; Alvarez, C.; Guillermo-Wann, C.; Cuellar, M.; Arellano, L.; Alvarez, C.; Guillermo-Wann, C.; Cuellar, M.; Arellano, L. A Model for Diverse Learning Environments: The Scholarship on Creating and Assessing Conditions for Student Success. In Higher Education: Handbook of Theory and Research; Smart, J.C., Paulsen, M.B., Eds.; Springer: New York, NY, USA, 2012 ; Volume 27.

25. Hurtado, S.; Milem, J.; Clayton-Pedersen, A.; Allen, W. Enhancing campus climates for racial/ ethnic diversity: Educational policy and practice. Rev. High. Educ. 1998, 21, 279-302. [CrossRef]

26. Milem, J.F.; Chang, M.J.; Antonio, A.L. Making Diversity Work on Campus: A Research-Based Perspective; American Association of Colleges and Universities: Washington, DC, USA, 2005.

27. Harris, L.M.; Campbell, J.T.; Brophy, A.L. (Eds.) Slavery and the University: Histories and Legacies; University of Georgia Press: Athens, GA, USA, 2019.

28. Wilder, C.S. Ebony and Ivy: Race, Slavery, and the Troubled History of America's Universities; Bloomsbury Publishing: New York, NY, USA, 2013.

29. Patton, L.D. My sister's keeper: A qualitative examination of mentoring experiences among African American women in graduate and professional schools. J. High. Educ. 2009, 80, 510-537. [CrossRef]

30. Patton, L.D.; Harper, S. Mentoring relationships among African American women in graduate and professional schools. New Dir. Stud. Serv. 2003, 104, 67-78. [CrossRef]

31. Taylor, M.; Turk, J.M.; Chessman, H.M.; Espinosa, L.L. Race and Ethnicity in Higher Education: 2020 Supplement; American Council on Education: Washington, DC, USA, 2020. 
32. Espinosa, L.L.; Turk, J.M.; Taylor, M.; Chessman, H.M. Race and Ethnicity in Higher Education: A Status Report; American Council on Education: Washington, DC, USA, 2019.

33. Bowman, S.R.; Kite, M.E.; Branscombe, N.R.; Williams, S. Developmental relationships of Black Americans in the academy. In Mentoring Dilemmas: Developmental Relationships within Multicultural Organizations; Murrell, A.J., Crosby, F.J., Ely, R.J., Eds.; Lawrence Erlbaum Associates: Mahwah, NJ, USA, 1999; pp. 21-46.

34. Kim, Y.K.; Sax, L.J. Student-faculty interactions in research universities: Differences by student gender, race, social class, and first-generation status. Res. High. Educ. 2009, 50, 437-459. [CrossRef]

35. Strayhorn, T. The role of supportive relationships in facilitating African American Males' success in college. NASPA J. 2008, 45, 26-48. [CrossRef]

36. Colbeck, C.L.; Cabrera, A.F.; Terenzini, P.T. Learning professional confidence: Linking teaching practices, students' selfperceptions, and gender. Rev. High. Educ. 2001, 24, 173-191. [CrossRef]

37. Cole, D.G. Do interracial interactions Matter? An examination of student-faculty contact and intellectual self-concept. J. High. Educ. 2007, 78, 249-281.

38. McCoy, D.L.; Winkle-Wagner, R.; Luedke, C.L. Colorblind mentoring? Exploring white faculty mentoring of students of color. J. Divers. High. Educ. 2015, 8, 225.

39. Cole, D.; Jackson, J. Racial Integration in Higher Education and Students' Educational Satisfaction 50 years beyond Brown. In Brown v Board of Education: Its Impact on Public Education; Edley, C., Jr., Byrne, D.N., Eds.; Thurgood Marshall Scholarship Punch: New York, NY, USA, 2005; pp. 1954-2004.

40. Solórzano, D.G.; Ceja, M.; Yosso, T. Critical race theory, racial microaggressions, and campus racial climate: The experiences of African American college students. J. Negro Educ. 2000, 69, 60-73.

41. Cole, D.G. The role of faculty contact on minority students' educational gains. J. Profr. 2010, 3, 1-16.

42. Cole, D.G. The effects of student-faculty interactions on minority students' college grades: Differences between aggregated and disaggregated data. J. Profr. 2010, 3, 137-160.

43. Hurtado, S.; Eagan, M.K.; Tran, M.C.; Newman, C.B.; Chang, M.J.; Velasco, P. “We do science here”: Underrepresented students' interactions with faculty in different college contexts. J. Soc. Issues 2011, 67, 553-579. [CrossRef] [PubMed]

44. Lundberg, C.A.; Schreiner, L.A. Quality and frequency of faculty-student interaction as predictors of learning: An analysis by student race/ethnicity. J. Coll. Stud. Dev. 2004, 45, 549-656. [CrossRef]

45. Anaya, G.; Cole, D. Latina/o student achievement: Exploring the influence of student-faculty interaction on college grades. J. Coll. Stud. Dev. 2001, 42, 3-14.

46. Smith, W.A.; Hung, M.; Franklin, J.D. Racial battle fatigue and the miseducation of Black men: Racial microaggressions, societal problems, and environmental stress. J. Negro Educ. 2011, 80, 63-82.

47. Linder, C.; Quaye, S.J.; Lange, A.C.; Roberts, R.E.; Lacy, M.C.; Okello, W.K. A student should have the privilege of just being a student: Student activism as labor. Rev. High. Educ. 2019, 42, 37-62. [CrossRef]

48. Keats, P.A. Vicarious witnessing in European concentration camps: Imagining the trauma of another. Traumatology 2005, 11, 171-187. [CrossRef]

49. Silverman, J.; Singh, N.N.; Carmanico, S.J.; Lindstrom, K.A.; Best, A.M.; Clearfield, S. Psychological distress and symptoms of posttraumatic stress disorder in Jewish adolescents following a brief exposure to concentration camps. J. Child. Fam. Stud. 1999, 8, 71-89. [CrossRef]

50. Alderman, D.H.; Butler, D.L.; Hanna, S.P. Memory, slavery, and plantation museums: The River Road Project. J. Herit. Tour. 2015, 11, 209-218. [CrossRef]

51. Carter, P.; Butler, D.L.; Alderman, D.H. The house that story built: The place of slavery in plantation museum narratives. Prof. Geogr. 2014, 66, 547-557. [CrossRef]

52. Garibay, J.C.; West, C.P.; Mathis, C. “It affects me in ways that I don't even realize”: Black student responses to a university's historical involvement in slavery. J. Coll. Stud. Dev. 2020, 61, 697-716. [CrossRef]

53. Hartman, S.V. Scenes of Subjection: Terror, Slavery, and Self-Making in Nineteenth-Century America; Oxford University Press: New York, NY, USA, 1997.

54. Hartman, S.V. Lose Your Mother: A Journey along the Atlantic Slave Route; Farrar, Straus and Giroux: New York, NY, USA, 2007.

55. Tillet, S. Sites of Slavery: Citizenship and Racial Democracy in the Post-Civil. Rights Imagination; Duke University: Durham, NC, USA, 2012.

56. Dumas, M.J. Against the dark: Antiblackness in education policy and discourse. Theory Pract. 2016, 55, 11-19. [CrossRef]

57. Sharpe, C.E. In the Wake: On Blackness and Being; Duke University Press: Durham, NC, USA, 2016.

58. Dancy, T.E.; Edwards, K.T.; Davis, E.J. Historically white universities and plantation politics: Anti-Blackness and higher education in the Black lives matter era. Urban. Educ. 2018, 53, 176-195. [CrossRef]

59. Squire, D.; Williams, B.C.; Tuitt, F. Plantation Politics and Neoliberal Racism in Higher Education: A Framework for Reconstructing Anti-Racist Institutions. Teach. Coll. Rec. 2018, 120, 1-19. [CrossRef]

60. Womack, S. I know I can't: The negative effects of post traumatic slave syndrome's on the well-being of African American college students. Vt. Connect. 2016, 37, 119-125.

61. Dorr, G.M. Segregration's Science: Eugenics and Society in Virginia; University of Virginia Press: Charlottesville, VA, USA, 2008. 
62. McInnis, M.D.; Nelson, L.P. (Eds.) Educated in tyranny: Slavery at Thomas Jefferson's University; University of Virginia Press: Charlottesville, VA, USA, 2019.

63. Williamson, J.A. In defense of themselves: The Black student struggle for success and recognition at predominantly white colleges and universities. J. Negro Educ. 1999, 68, 92-105. [CrossRef]

64. Kendi, I. The Black Campus Movement: Black Students and the Racial Reconstitution of Higher Education, 1965-1972; Palgrave Macmillan: New York, NY, USA, 2012.

65. Wun, C. Against captivity: Black girls and school discipline policies in the afterlife of slavery. Educ. Policy 2016, 30, 171-196. [CrossRef]

66. Garcia, N.M.; López, N.; Vélez, V.N. QuantCrit: Rectifying quantitative methods through critical race theory. Race Ethn. Educ. 2018, 21, 149-157. [CrossRef]

67. Gillborn, D.; Warmington, P.; Demack, S. QuantCrit: Education, policy, 'Big Data' and principles for a critical race theory of statistics. Race Ethn. Educ. 2018, 21, 158-179. [CrossRef]

68. Johnston-Guerrero, M.P. The (mis)uses of race in research on college students: A systematic review. J. Committed Soc. Chang. Race Ethn. 2017, 3, 6-41. [CrossRef]

69. Sen, M.; Wasow, O. Race as a 'Bundle of Sticks': Designs that estimate effects of seemingly immutable characteristics. Annu. Rev. Political Sci. 2016, 19, 499-522. [CrossRef]

70. Ladson-Billings, G.; Tate, W.F. Toward a critical race theory of education. Teach. Coll. Rec. 1995, 97, 47-68.

71. Cabrera, N.L. Where is the racial theory in Critical Race Theory? A Constructive Criticism of the Crits. Rev. High. Educ. 2018, 42, 209-233. [CrossRef]

72. Ginzberg, E. Lázaro Cárdenas: Gobernador de Michoacán (1928-1932); El Colegio de Michoacán, UMSNH, Instituto de Investigaciones Históricas: Zamora, Mexico, 1999.

73. Smith, W.A.; Yosso, T.J.; Solórzano, D.G. Challenging Racial Battle Fatigue on Historically White Campuses: A Critical Race Examination of Race-Related Stress. In Faculty of Color Teaching Predominantly White Colleges and Universities; Stanley, C.A., Ed.; Anker: Bolton, MA, USA, 2006; pp. 299-327.

74. American Educational Research Association, American Psychological Association, \& National Council on Measurement in Education. Standards for Educational and Psychological Testing; American Educational Research Association: Washington, DC, USA, 2014.

75. Reddick, R.J.; Pritchett, K.O. I don't want to work in a world of whiteness: White faculty and the mentoring relationships with Black students. J. Profr. 2015, 8, 54-84.

76. Cole, D.G. Student-Faculty Interactions of African American and White College Students at Predominantly White Institutions. Ph.D. Thesis, Indiana University, Bloomington, IL, USA, 1999.

77. Davis, R.B. Social support networks and undergraduate student academic-success related outcomes: A comparison of Black students on Black and White campuses. In College in Black and White: African American Students in Predominantly White and in Historically Black Public Universities; Allen, W.R., Epps, E.G., Haniff, N.Z., Eds.; State University Press of New York Press: Albany, NY, USA, 1991; pp. 147-153.

78. Mwangi, C.A.G.; Fries-Britt, S. Black within Black: The perceptions of Black immigrant collegians and their US college experience. About Campus 2015, 20, 16-23. [CrossRef]

79. Stewart, D.L. Being all of me: Black students negotiating multiple identities. J. High. Educ. 2008, 79, 183-207. [CrossRef]

80. Little, R.J.; Rubin, D.B. Statistical Analysis with Missing Data, 2nd ed.; Wiley: Hoboken, NJ, USA, 2002.

81. Kline, R.B. Principles and Practice of Structural Equation Modeling; Guilford Press: New York, NY, USA, 1998.

82. Cole, D.G. Constructive criticism: The role of student-faculty interactions on African American and Hispanic students' educational gains. J. Coll. Stud. Dev. 2008, 49, 587-605. [CrossRef]

83. Hu, L.; Bentler, P.M. Cutoff criteria for fit indexes in covariance structure analysis: Conventional criteria versus new alternatives. Struct. Equ. Modeling 1999, 6, 55. [CrossRef]

84. Browne, M.W.; Cudeck, R. Alternative Ways of Assessing Model Fit. In Testing Structural Equation Models; Bollen, K.A., Long, J.S., Eds.; Sage: Newbury Park, CA, USA, 1993; pp. 136-162.

85. Byrne, B.M. Structural Equation Modeling with EQS: Basic Concepts, Applications and Programming, 2nd ed.; Lawrence Erlbaum Associates, Inc.: Mahwah, NJ, USA, 2006.

86. McDonald, R.P.; Ho, M.-H.R. Principles and practice in reporting structural equation analyses. Psychol. Methods 2002, 7, 64-82. [CrossRef]

87. Hatcher, L.A. Step-By-Step Approach to Using the SAS System for Factor Analysis and Structural Equation Modeling; SAS Institute Inc.: Cary, NC, USA, 1994.

88. Garibay, J.C.; Mathis, C.; West, C. Black student views on higher education reparations at a university with an enslavement history. Race Ethn. Educ. 2021, in press.

89. Garibay, J.C.; Dache, A.; West, C.; Mathis, C. A critical analysis of higher education reparations at universities founded pre-Civil War. In Proceedings of the American Education Research Association Annual Meeting (Virtual), Online, 8-12 April 2021.

90. Stein, S. Universities, slavery, and the unthought of anti-Blackness. Cult. Dyn. 2016, 28, 169-187. [CrossRef] 
91. Tichavakunda, A.A. A critical race analysis of university acts of racial "redress": The limited potential of racial symbols. Educ. Policy 2021, 35, 304-322. [CrossRef]

92. Neville, K.M.; Parker, T.L. A breath of fresh air: Students' perceptions of interactions with African American faculty. J. Coll. Stud. Dev. 2017, 58, 349-364. [CrossRef] 